\title{
Prevalence of Hepatitis B Virus Infection and
} Factors Associated with Hepatitis B Virus Infection Among Pregnant Women Presented to Antenatal Care Clinics at Adigrat General
Hospital in Northern Ethiopia

This article was published in the following Dove Press journal: International Journal of Women's Health

Hailay Kinfe'

Endalew Gemechu Sendo (iD) ${ }^{2}$

Ketema Bizuwork Gebremedhin (ID) 2

'St. Petros Hospital, Addis Ababa, Ethiopia; ${ }^{2}$ School of Nursing and Midwifery, College of Health Sciences, Addis Ababa University, Addis Ababa, Ethiopia
Correspondence: Ketema Bizuwork Gebremedhin

Email ketema2005@yahoo.com
Background: Hepatitis B infection is among the most common public health concerns globally, particularly in low- and middle-income countries. The prevalence of hepatitis B infection is more common among most vulnerable populations, including pregnant women. However, there are limited studies on hepatitis B virus infection among pregnant women in low-income countries, including Ethiopia, and the previous studies focused on the general population rather than the pregnant women. The purpose of this study was to estimate the prevalence and examine factors associated with hepatitis B virus infection among pregnant women in the Northern Ethiopia.

Methods: nstitution-based cross-sectional study design and a structured face-to-face interview were used to collect data from the study participants. Simple random sampling method was used to select eligible study participants. Data were entered using EpiData version 3.1, and SPSS version 20 was used for the data analysis. We analyzed the data to examine factors associated with hepatitis B virus infection using binary and multivariable logistic regression models.

Results: The overall prevalence of hepatitis B virus infection among the study participants was $9.2 \%$. The majority (46.7\%) of the study participants infected by hepatitis B were in the age group 25-34 years. The study found that married study participants were more likely to be infected by hepatitis B when compared to the unmarried study participants. Having history of abortion $[\mathrm{OR}=0.12(95 \% \mathrm{CI}: 0.03,0.47), P<0.01]$ and having history of tattooing $[\mathrm{OR}=0.21$ (95\% CI: $0.07,0.62), P<0.01]$ were found to be statistically significantly associated with the prevalence of hepatitis B virus infection among pregnant women.

Conclusion: A significant number of pregnant women participating in the study were infected by the hepatitis $\mathrm{B}$ virus which needs efficient intervention to reduce the infection rate. Further, educational status, having history of surgery, dental procedure, ear piercing, abortion and tattooing were found statistically to be significant before controlling for confounders. But, after controlling for confounders, only having history of tattooing and having history of abortion were found to be independent factors affecting the prevalence of the infection.

Keywords: pregnancy, hepatitis B infection, hepatitis B virus, Ethiopia

\section{Background}

Hepatitis B infection is among the leading public health problems globally. ${ }^{1-3}$ The disease is caused by hepatotropic deoxyribonucleic acid (DNA) virus and 
occurs through the immune-mediated killing of infected liver cells. ${ }^{2,4}$ The virus is more potent compared to human immunodeficiency virus (HIV). ${ }^{5}$ According to the World Health Organization, an estimated 257 million people were living with chronic hepatitis B virus infection, including 2.7 million co-infected with $\mathrm{HIV}$, in 2015 , $^{1,6}$ with a prevalence of hepatitis B virus infection in Africa of $6.1 \%$ and in Western Pacific countries of $6.2 \%$; a total of $68 \%$ of infected people were in Africa and West Pacific Asia. ${ }^{6}$ Further, $5-15 \%$ of populations in developing and poor-income countries are chronic carriers of hepatitis $\mathrm{B}$ infection. $^{7}$ Moreover, WHO reported that hepatitis is responsible for 1.34 million deaths, which is equivalent to deaths due to tuberculosis but higher than deaths due to $\mathrm{HIV}$ in $2015 .^{6}$ In actual fact, currently, worldwide an estimated two billion people were exposed and/or currently living with the virus hepatitis $\mathrm{B}^{7}$ and over 240 million were found to be in chronic state. ${ }^{8}$ Further, a high number (1.8 million) of children under five years are living with the hepatitis B virus. ${ }^{9}$ Although chronic carriers of the disease are more prevalent among males compared to females, ${ }^{10}$ neonates acquire the disease through vertical transmission from women infected with the disease, ${ }^{11}$ which may lead them to a chronic state in as many as $90 \%{ }^{12}$ In endemic areas, it has been established that the main route of acquisition of the disease is from mother to child (MTCT), especially when the mother is HBeAg-positive. ${ }^{13}$ Additionally, if they do not take any prophylaxis, women acutely infected with the disease or who are chronic carriers of the virus may transmit it to their newborn. ${ }^{14}$ Infants born to hepatitis B-infected mothers, but negative to $\mathrm{HBeAg}$, have a risk of $10-40 \%$ of acquiring the infection, while those born to infected mothers and positive for $\mathrm{HBeAg}$ have a $90 \%$ risk of acquiring the infection. ${ }^{15}$

In addition, the infection can be prevented by means of the vaccine launched by the World Health Organization in 1992 to be incorporated into the national immunization program for those countries whose prevalence of the infection is greater than two percent. ${ }^{16}$ There aretwo main strategies in preventing the infection: I) behavioral modification: changing sexual practice and strict screening of blood donors, which is more effective for developed countries than developing countries, as in developing countries the riskiest groups are neonates and newborns; II) developing passive disease protective antibody (passive immunization) through vaccinating by $0.13 \mathrm{~mL} / \mathrm{kg}$ HBIG for newborns of infected mothers in combination with recombinant vaccine ${ }^{16,17}$; adhering to these two strategies is among the best ways of preventing the transmission of the virus from an infected and/ or carrier individual to a healthy individual. Non-compliance with the preventive method results in transmission of the disease from infected to uninfected individuals, especially to the newborn neonates ${ }^{11,13}$, which hinders the meeting of the World Health Organization goal to eliminate viral hepatitis by $2030{ }^{3}$ The problem is notoriously more prevalent in Africa and Western Pacific countries. ${ }^{6}$ As an African country, Ethiopia is ranked from medium to high in terms of endemicity of the disease. ${ }^{18}$

In Ethiopia, even if there is lack of data representing the prevalence of hepatitis B infection nationally, according to the findings of some individual studies, the country is regarded as having a high burden of the disease. ${ }^{18}$ As evidence, two recent systematic reviews and meta-analysis revealed that the overall prevalence of hepatitis B infection among the total population ranged from $6 \%$ to $7.4 \%,{ }^{19,20}$ while among pregnant women the range was $5 \%$ to $7 \%,{ }^{20,21}$ a primary source of infection for the newborn. This finding is supported by a number of other studies conducted in the country, which found that the prevalence of hepatitis $\mathrm{B}$ infection among pregnant women ranged from $4.3 \%$ to $7.9 \% .^{12,22-24}$

This endemic level of the infection in the country is; in the presence of effective potential preventive strategies, even if technical guidance and financial support from the international community are low in the country. ${ }^{25}$ Althoughthe disease is found at endemic level among all populations and/or pregnant women in the country, there is no study conducted in the northern part of Ethiopia. Therefore, the purpose of this study was to estimate the prevalence and factors associated with hepatitis B virus infection among pregnant women attending antenatal care clinic of Adigrat General Hospital, Tigray, Ethiopia.

\section{Methods}

\section{Study Setting and Period}

The study was conducted at Adigrat general hospital, which is found in Tigray regional state in the northern part of Ethiopia. According to the 2007 national census, Adigrat town has 57,572 total population, and more than half are women. ${ }^{26}$ The hospital provides inpatient services like admission and treatment of patients with medical and/ or surgical cases, obstetric and/or gynecologic care services, outpatient services like antenatal care service, mother and child health care services, family planning, 
ART clinic services etc. This study was conducted from February 1 to March 30, 2019.

\section{Study Design and Sample Size Determination}

Institutional-based cross-sectional study design was used to examine the prevalence and factors associated with hepatitis $\mathrm{B}$ infection among pregnant women attending the ANC clinic at Adigrat General Hospital. The sample size was calculated based on a single population proportion formula $\mathrm{n}=\frac{(z \alpha / 2) 2 P(P-1)}{\mathrm{d}^{2}}$ where:

$\mathrm{n}=$ final sample size calculated

$\mathrm{d}=$ desired precision

$\mathrm{z}=$ confidence interval

$\mathrm{P}=$ previous estimated prevalence of hepatitis $\mathrm{B}$ infection among pregnant women

by taking $8.1 \%$ prevalence of $\mathrm{HBV}$ infection from a previous study, ${ }^{27}$ desired precision of $3 \%$, a $95 \%$ confidence level and 10\% non-response rate, then, the final sample size was 350 . Since our source population is less than 10,000 , namely 650 , we used the correction formula. $\mathrm{nf}=\frac{n}{1+\frac{n}{N}}=240$ including $10 \%$ non-response rate, where, $\mathrm{nf}=$ final sample size. Accordingly, the final sample size was 240 pregnant women attending the ANC clinic at Adigrat General Hospital.

\section{Study Subjects and Sampling Procedure}

In the normal maternal care procedure of the hospital, pregnant women were triaged and assigned to the clinic as a routine service delivery procedure in the antenatal care clinic of the hospital. They were then permitted to enter into the ANC room one by one for routine follow-up care. All pregnant women with confirmed pregnancy were eligible to be enrolled in this study; those who met the inclusion criteria were interviewed after we promptly explained the purpose of the study. Pregnant women who were critically sick and unable to respond to the interview and those who did not volunteer to participate in the study were excluded. Systematic random sampling method was used to select the eligible study participants. The determined number of pregnant women was recruited within four weeks' working days.

\section{Study Variables \\ Dependent Variable: HBsAg Serostatus Independent Variables}

Socio-demographic and other background and/or clinical characteristics were recorded, which included age, blood transfusion, history of dental procedure, ear/nose piercing, educational level, risky sexual behavior, tattooing, occupation, marital status, income level, gravidity, history of dental procedure, history of surgical procedure and abortion.

\section{Data Collection Procedure and Quality Control}

Socio-demographic and other pertinent data were collected by trained data collectors using a pre-tested standard questionnaire adapted from study conducted in Ethiopia. ${ }^{28}$ Socio-demographic information was collected (maternal age, marital status, educational level, occupation, income and gravidity), while other pertinent data included risky socio-cultural and behavioral practice (tattoo, ear/nose piercing, abortion and multiple sexual partners) and hospital-associated factors (history of hospitalization, surgery and dental procedure). To ensure its consistency, the English version of the questionnaire was translated into local language (Tigrigna) and then back to English by language experts. After a brief explanation of the aim of the study, the participants were invited to take part in the study voluntarily. Due to the reason that, the national guideline of the country forces, every pregnant woman should be tested for both HIV/AIDS and HBsAg in the hospital before going take other pregnancy-related cares, the outcome variable; seroprevalence of the study participants were determined by reviewing chart of the study participants for recent information about the result of the HBsAg test. Further, based on the national guideline, the hospital laboratory used rapid diagnostic test and/or laboratory immunoassay method and followed all standards of safety, quality and performance expected. The standards of safety, quality and performance of the laboratories were regularly evaluated by national/regional/ zonal laboratory quality assurance teams of the country.

\section{Ethical Considerations}

The study was conducted based on the human research ethics declaration of Helsinki 2008. ${ }^{29}$ Therefore, to all pass through the obligations of the declaration, initially, the study proposal was submitted to Institutional Health Research Ethics Review Committee (IHRERC) of the College of Health Science of Addis Ababa University. Then, the review board assessed, commented and approved it, by confirming the study does not have any ethical issue that may harm the study participants. Therefore, the study obtained an official ethical 
clearance letter from the Institutional Health Research Ethics Review Committee (IHRERC) of the university. Additionally, official permission was received from Adigrat Zonal Health Bureau and Adigrat General Hospital Administration. Moreover, all the study participants were informed about the study and assured about the confidentiality, protection and anonymity of data. Written consent was obtained from each study participant before the data collection and participation in the study. Moreover, assent was taken in written form from the husband of the pregnant women participating in the study for those whose age was less than 18 years.

\section{Data Analysis}

After checking for completeness and consistency of the collected information, the data were entered into EpiData version 3.1, and then the data were transferred to SPSS version 20 for further analysis. Descriptive statistical analysis was used to determine the socio-demographic background characteristics of study participants and prevalence of HBV. Association between the possible risk factors with prevalence of HBV infection was determined using bivariate and multivariate logistic regression analysis. Odds ratio (OR) and 95\% CI were used as a measure of strength of association. In all cases $p$-value less than 0.05 was considered to be statistically significant.

\section{Results}

\section{Socio-Demographic Characteristics of the Study Participants}

The majority of the study participants were in the age category of 15-34 years. The mean age of the study participants was $26.07 \pm 5.2$. About three-fourths (70.4\%) of the study participants were married. About two-thirds (64.2\%) of the study participants had income per month of $<116 \$$. The majority $(81.3 \%)$ of the study participants were primi-gravid in their pregnancy history. The majority (83.3\%) of the study participants had less than or equal to two live births. About one-fourth (25.8\%) of the study participants had history of admission in the hospital and/ or health center. The majority $(90.8 \%)$ of the study participants had experienced ear piercing, while $14.6 \%$ of the study participants had history of tattooing. About $7 \%$ of the study participants had history of abortion. Almost $22 \%$ of the study participants' husbands were polygamous (Table 1).

\section{Prevalence of Hepatitis B Infection}

\section{Among the Study Participants}

About $9 \%$ of the study participants were positive for hepatitis B surface antigen, while the rest were negative (Figure 1). Among those positive for hepatitis B surface antigen, the majority $(8.8 \%, 7.9 \%, 7.5 \%, 7.1 \%)$ of them had history of ear piercing in their traditional practice, younger age group (15-34) years of age, para-gravida in their pregnancy history, unemployed in their occupation, respectively. Further, equivalent numbers of the pregnant women positive for hepatitis B surface antigen were married and unmarried, had higher income and lesser income, and had history of tattooing or not, (Table 2).

\section{Factors Associated with Hepatitis B Virus Infection}

In order to measure association of variables with dependent variable prevalence of hepatitis B virus infection, we used both bivariable and multivariable logistic regression analysis with significance level of less than 0.05 . Thus, bivariable logistic regression analysis revealed the following: the younger pregnant women, and those who were married were found more likely to acquire the infection, compared to the older pregnant women and pregnant unmarried women, respectively. However, both variables were not statistically significantly associated at $P<0.05$. Further, the bivariable logistic regression analysis revealed that educational status, having history of admission to the hospital, dental procedure, surgery, abortion and tattooing were found to be statistically significantly associated with the prevalence of hepatitis B virus infection among the pregnant women participating in the study (Table 2). However, after controlling for some confounders with multivariable logistic regression analysis, only variables like having history of abortion [OR $=0.12(95 \% \mathrm{CI}$ : $0.03,0.47), P<0.01]$ and history of tattooing [OR = 0.21 (95\% CI: $0.07,0.62), P<0.01]$ retained their significance at $P<0.05$ (Table 3).

\section{Discussion}

Indisputably, infection secondary to hepatitis B virus is the major public health problem globally, and is a leading cause of chronic hepatitis in low- and middle-income countries. ${ }^{7,8}$ Regarding the endemicity of the disease, the world has been classified into three sub-regions; high for $>8 \%$, intermediate for $2-8 \%$ and low for $<2 \%$ prevalence of hepatitis B infection among the populations. ${ }^{7,8,30,31}$ It is 
Table I Socio-Demographic Characteristics of the Study Participants

\begin{tabular}{|l|l|l|l|}
\hline Variables & Frequency & Percent & $\begin{array}{l}\text { Mean with } \\
\text { SD }\end{array}$ \\
\hline Age & & & $26.07 \pm 5.2$ \\
$15-24$ & 106 & 44.2 & \\
$25-34$ & 112 & 46.7 & \\
$35-49$ & 22 & 9.1 & \\
\hline
\end{tabular}

Marital status

\begin{tabular}{l|l|l|l}
\hline Married & 169 & 70.4 & \\
Unmarried & 71 & 29.6 & \\
\hline
\end{tabular}

Occupational status

\begin{tabular}{|l|l|l|l|}
\hline Employed & 52 & 21.7 & \\
Unemployed & 188 & 78.3 & \\
\hline $\begin{array}{l}\text { Monthly income in \$ } \\
<116\end{array}$ & 154 & 64.2 & $2952.2 \pm 1619$ \\
$\geq 116$ & 86 & 35.8 & \\
\hline
\end{tabular}

Educational status

\begin{tabular}{|c|c|c|}
\hline $\begin{array}{l}\text { Not read and write } \\
\text { Read and write } \\
\text { Attended formal } \\
\text { education }\end{array}$ & $\begin{array}{l}12 \\
18 \\
210\end{array}$ & $\begin{array}{l}5 \\
7.5 \\
87.5\end{array}$ \\
\hline \multicolumn{3}{|l|}{ History of tattooing } \\
\hline $\begin{array}{l}\text { Had } \\
\text { Not }\end{array}$ & $\begin{array}{l}35 \\
205\end{array}$ & $\begin{array}{l}14.6 \\
85.4\end{array}$ \\
\hline
\end{tabular}

Number of pregnancy

\begin{tabular}{|l|l|l|l|}
\hline Primi-gravida & 45 & 18.8 & \\
Para-gravida & 195 & 81.3 & \\
\hline
\end{tabular}

Number of live birth

\begin{tabular}{|c|c|c|}
\hline $\begin{array}{l}\leq 2 \\
\geq 3\end{array}$ & $\begin{array}{l}200 \\
40\end{array}$ & $\begin{array}{l}83.3 \\
16.7\end{array}$ \\
\hline \multicolumn{3}{|c|}{ History of admission } \\
\hline $\mathrm{Had}$ & 62 & 25.8 \\
\hline Not & 178 & 74.2 \\
\hline \multicolumn{3}{|c|}{ History of dental procedure } \\
\hline $\mathrm{Had}$ & 32 & 13.3 \\
\hline Not & 208 & 86.7 \\
\hline \multicolumn{3}{|c|}{ History of surgery } \\
\hline $\mathrm{Had}$ & 15 & 6.3 \\
\hline Not & 225 & 93.8 \\
\hline
\end{tabular}

(Continued)
Table I (Continued).

\begin{tabular}{|c|c|c|c|}
\hline Variables & Frequency & Percent & $\begin{array}{l}\text { Mean with } \\
\text { SD }\end{array}$ \\
\hline $\mathrm{Had}$ & 16 & 6.7 & \\
\hline Not & 224 & 93.3 & \\
\hline \multicolumn{4}{|l|}{ History of ear piercing } \\
\hline $\mathrm{Had}$ & 218 & 90.8 & \\
\hline Not & 22 & 9.2 & \\
\hline \multicolumn{4}{|c|}{ Husbands' marriage condition } \\
\hline Have extra wife & 52 & 21.7 & \\
\hline Not have extra wife & 188 & 78.3 & \\
\hline \multicolumn{4}{|c|}{ Husbands' marriage history } \\
\hline Married before & 47 & 19.6 & \\
\hline Not married before & 193 & 80.4 & \\
\hline
\end{tabular}

Notes: Unemployed includes petty trader, homemade, house wife; Unmarried includes single, and divorced.

known that the main route of transmission for the virus is from mother to child during pregnancy and/or labor and delivery, ${ }^{31}$ and $90 \%$ of infants who acquired the infection during labor and delivery will become chronic carriers the disease. ${ }^{21}$ The World Health Organization recommends to screen pregnant women for hepatitis B virus infection at the first prenatal visit ${ }^{4,30}$ in order to prevent perinatal transmission with the help of the main strategies: active

\section{Serology test status for HBsAG}

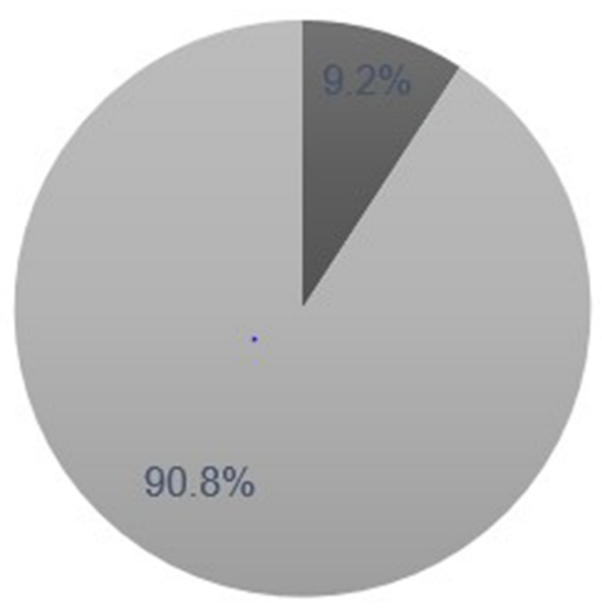

Figure I Serology test status of the pregnant women, $N=240$. Abbreviation: HBsAG, Hepatitis B surface antigen. 
Table 2 Association of Variables Under Bivariate Logistic Regression Analysis, $N=240$

\begin{tabular}{|c|c|c|c|c|}
\hline \multirow[t]{2}{*}{ Variables } & \multicolumn{2}{|c|}{ Sero-Status for HBsAg } & \multirow[t]{2}{*}{ OR (95\% Cl) } & \multirow[t]{2}{*}{$P$ value } \\
\hline & Positive 22 (9.2\%) & Negative: 218 (90.8) & & \\
\hline Age & & & & 0.75 \\
\hline I5-24 & $9(3.7)$ & $97(40.4)$ & $\mathrm{I} .70(0.42,6.87)$ & \\
\hline $25-34$ & $10(4.2)$ & $102(42.5)$ & $\mathrm{I} .6 \mathrm{I}(0.4 \mathrm{I}, 6.40)$ & \\
\hline $35-49$ & $3(1.3)$ & $19(7.9)$ & 1 & \\
\hline Marital status & & & & 0.09 \\
\hline Married & $12(5.00)$ & $157(65.4)$ & $2.15(0.88,5.22)$ & \\
\hline Unmarried & $10(4.2)$ & $6 \mathrm{I}(25.8)$ & I & \\
\hline Occupational status & & & & 0.90 \\
\hline Employed & $5(2.1)$ & $47(19.6)$ & $0.94(0.33,2.67)$ & \\
\hline Unemployed & $17(7.1)$ & $|7|(7 \mid .2)$ & 1 & \\
\hline Monthly income in EB & & & & 0.15 \\
\hline$<3500$ & II (4.6) & $143(59.6)$ & I.9I $(0.79,4.60)$ & \\
\hline$\geq 3500$ & II (4.6) & $75(31.2)$ & 1 & \\
\hline Educational status & & & & $0.04 * *$ \\
\hline Not read and write & $0(0.0)$ & $12(5.0)$ & - & \\
\hline Read and write & $5(2.1)$ & $13(5.4)$ & $0.23(0.07,0.72)$ & \\
\hline Formally educated & $17(7.1)$ & $193(80.4)$ & I & \\
\hline Number of pregnancy & & & & 0.94 \\
\hline Primi-gravida & $4(1.7)$ & $4 \mid(17.1)$ & $1.04(0.34,3.24)$ & \\
\hline Para-gravida & $18(7.5)$ & 177 (73.7) & I & \\
\hline Number of live birth & & & & 0.69 \\
\hline$\leq 2$ & $19(7.9)$ & I8I (75.4) & $0.77(0.22,2.75)$ & \\
\hline$\geq 3$ & $3(1.3)$ & $37(15.4)$ & I & \\
\hline History of admission & & & & $0.00 * *$ \\
\hline $\mathrm{Had}$ & $8(3.3)$ & $48(20.0)$ & $0.16(0.06,0.41)$ & \\
\hline Not & $14(5.9)$ & $170(70.8)$ & 1 & \\
\hline History of dental procedure & & & & $0.01 * *$ \\
\hline $\mathrm{Had}$ & $7(2.9)$ & $25(10.4)$ & $0.28(0.10,0.75)$ & \\
\hline Not & $15(6.3)$ & $193(80.4)$ & I & \\
\hline History of surgery & & & & $0.00 * *$ \\
\hline $\mathrm{Had}$ & $6(2.5)$ & $9(3.7)$ & $0.12(0.04,0.36)$ & \\
\hline Not & $16(6.7)$ & $209(87.1)$ & I & \\
\hline History of abortion & & & & $0.00 * *$ \\
\hline Had & $8(3.3)$ & $8(3.3)$ & $0.07(0.02,0.20)$ & \\
\hline Not & $14(5.9)$ & $210(87.5)$ & 1 & \\
\hline History of ear piercing & & & & 0.44 \\
\hline $\mathrm{Had}$ & $21(8.8)$ & $197(82.1)$ & $0.45(0.06,3.50)$ & \\
\hline Not & I $(0.4)$ & $21(8.7)$ & 1 & \\
\hline History of tattooing & & & & $0.00 * *$ \\
\hline Had & II (4.6) & $24(10.0)$ & $8.08(3.20,20.64)$ & \\
\hline Not & II (4.6) & $194(80.8)$ & 1 & \\
\hline
\end{tabular}

Notes: Unemployed includes petty trader, homemade, house wife; Unmarried includes single, cohabited and divorced. I = reference, **Significant. Abbreviations: $\mathrm{HBsAg}$, Hepatitis B surface antigen; EB, Ethiopian Birr. 
Table 3 Association of Variables Under Multivariate Logistic Regression Analysis, $N=240$

\begin{tabular}{|l|l|l|l|l|l|}
\hline Variables & $\boldsymbol{\beta}$ & SE & $\begin{array}{l}\text { Wald } \\
\chi^{2}\end{array}$ & $\begin{array}{l}\text { OR (95\% } \\
\mathbf{C I})\end{array}$ & $\boldsymbol{P}$-value \\
\hline $\begin{array}{l}\text { History of } \\
\text { abortion } \\
\begin{array}{l}\text { History of } \\
\text { tattooing }\end{array}\end{array}$ & -2.13 & 0.70 & 9.3 & $\begin{array}{l}0.12(0.03, \\
0.47)\end{array}$ & $0.00^{* *}$ \\
\hline
\end{tabular}

Note: **Significant.

Abbreviations: $\beta$, beta; $\mathrm{SE}$, standard error; $\mathrm{OR}$, odds ratio; $\mathrm{Cl}$, confidence interval.

and passive vaccination to the mother and the newborn given within the appropriate period. ${ }^{4}$ Therefore, this study investigated the prevalence of hepatitis B virus infection and its associated factors among pregnant women in the northern part of Ethiopia. The study revealed that more than $9 \%$ of the study participants were positive for hepatitis B surface antigen. This finding is in line with worldwide cut-off points for higher endemicity level in studies from developing countries. ${ }^{32,33}$ This indicates that the prevention and vaccination status of pregnant women towards hepatitis B is low, which leads to the higher rate of chronic hepatitis B infection for babies born to hepatitis $\mathrm{B}$ infection-positive mothers. The sero-prevalence of hepatitis $\mathrm{B}$ infection among pregnant women found by this study is higher than study findings of four studies from Ethiopia. ${ }^{12,22-24}$ Similarly, it is higher than study findings from developing countries such as India and Vietnam. ${ }^{33,34}$ However, it is lower than study findings from Nigeria. ${ }^{35}$ This difference may be due to difference in awareness level of the study participants towards the infection, difference in socioeconomic level, sample size and/or study season, study design, methods used for investigation of the virus or government attention level for the infection. The reasons stated here above for the difference in prevalence of the infection among pregnant women in developing countries are cited by some studies as reasons for the difference of the prevalence in their studies. ${ }^{12}$

Among many possible factors affecting prevalence of hepatitis B infection among pregnant women tested for the association in this study, history of abortion and history of tattooing were statistically significant both under bivariate and multivariate logistic regression analysis. This indicates having history of tattooing and abortion makes the women most susceptible for the infection. However, this finding contradicts a study from the northwestern part of Ethiopia. ${ }^{23}$ This may be due to abortion and/or tattooing procedure done at the northeastern part of Ethiopia being relatively safe and not facilitating the transmission of the virus, while this is not the case in the northern part of Ethiopia. Further, according to the findings of this study women having history of tattooing and abortion were more likely to be infected by hepatitis B among the pregnant women participating in the study. This may be due to the tattooing procedure and abortion which may be done by unskilled and/or traditional personnel. Additionally, they may use unclean materials for the procedure. Further, in regard to the history of abortion, this finding is in line with a study from the southern part of Ethiopia. However, the findings of that study contradicts our findings with the history of tattooing. ${ }^{22}$

According to the findings of this study, para-gravid women in respect to their pregnancy number were more likely to be infected by hepatitis B compared to the primigravid pregnant women. This may be due to the higher number of visits to the hospital making them susceptible for hospital-acquired infection, lowering of immunity as compared to the younger pregnant women. The findings of this study with regard to the infection level among paragravid pregnant women contradicts those of a study from the southern part of Ethiopia. ${ }^{24}$

This may be due to the difference in awareness level of the infection among the study participants, difference in sample size of the study, season of the study, method used to investigate the sero-prevalence of the study.

Further, according to our findings, those study participants who had "employed" as their occupational status were less likely to be infected by the hepatitis B virus compared to unemployed pregnant women participating in the study. This may be due to the employed study participants having good awareness about the transmission and prevention route of the disease compared to the unemployed pregnant women participating in the study. The most probable reason for good awareness of the transmission and prevention method of the disease among employed pregnant women participating in the study was their higher educational level compared to unemployed pregnant women participating in the study. This finding is in line with the study from the southern part of Ethiopia. ${ }^{12,24}$ This may be due to the population of the two study areas having the same socioeconomic status and educational status. Therefore, it is important to regularly monitor the infection level among pregnant women and employ influencing factors that help prevent and 
control the infection among these most vulnerable populations.

Although the study was conducted in a single institution, the study contributes significant information for policy makers, government officers, researchers and nongovernmental stakeholders participating in the control and prevention of the disease.

\section{Limitation of the Study}

This cross-sectional study cannot determine cause and effect. Timing of the study period is also a limitation of the study as results are limited by the cross-sectional time period. The information obtained from mothers could be subject to recall bias, social acceptability bias, interviewer bias, and responder bias.

\section{Conclusion}

Maternal health is a basic concern for the global community. Therefore, the global community including the World Health Organization is striving to consistently maintain health for women; however, it still needs strong attention. This study concluded that the prevalence of hepatitis $\mathrm{B}$ infection among pregnant women participating in this study is at the cut-off point of higher-level hepatitis endemicity. The independent factors related to the prevalence of hepatitis B virus infection were having history of tattooing and/or history of abortion.

\section{Abbreviations}

HBsAg, hepatitis B surface antigen; HIV, human immunodeficiency virus; DNA, deoxyribo nucleic acid; WHO, World Health Organization; MTCT, mother to child transmission; ANC, antenatal care; AIDS, acquired immune deficiency syndrome; IHRERC, Institutional Health Research Ethics Review Committee; HBV, hepatitis $B$ virus.

\section{Data Sharing Statement}

The datasets for the study are available from the corresponding author on reasonable request.

\section{Ethics Approval and Consent to Participate}

Ethical clearance to conduct this research was sought from the Research and Ethical Review Committee of the School of Nursing and Midwifery, College of Health Sciences, Addis Ababa University. Permission to conduct the study was obtained from the concerned office. Participants of the study were informed about the objective of the study and asked to provide informed voluntary written consent. Further, assent was taken from her husband for those whose age was less than 18 years. To keep the confidentiality of any information provided by study subjects, the data collection procedure was anonymous.

\section{Acknowledgments}

The authors thank Addis Ababa University for their financial support and Addis Ababa Health Bureau for providing permission to conduct the study. We would also like to thank all study participants, data collectors and supervisors.

\section{Funding}

The study was funded by the Addis Ababa University postgraduate office. However, the funding organization had no role in the design of the study and collection, analysis, and interpretation of data and in writing the manuscript.

\section{Disclosure}

The authors declare that they do not have any conflicts of interest in this work.

\section{References}

1. Liu J, Liang W, Jing W, Liu M. Countdown to 2030: eliminating hepatitis B disease, China. Bull World Health Organ. 2019;97 (3):230-238. doi:10.2471/BLT.18.219469

2. Guimarães LCDC, Brunini S, Guimarães,RA, et al. Epidemiology of hepatitis B virus infection in people living in poverty in the central-west region of Brazil. BMC Public Health. 2019;19(1):443. doi:10.1186/s12889-019-6828-8

3. Yim SY, Kim JH. The epidemiology of hepatitis B virus infection in Korea. Korean J Intern Med. 2019;34(5):945-953. doi:10.3904/ kjim.2019.007

4. WHO. Guidelines for the Prevention, Care and Treatment of Persons with Chronic Hepatitis b Infection. Geneva; 2015. Available from: http://wwwwhoint/hiv/topics/hepatitis/en/. Accessed February 18, 2020.

5. WHO. State of the worldess vaccination and immunization. 2009. Available from: https://appswhoint/iris/bitstream/handle/10665/44169/ 9789241563864_engpdf?sequence=1. Accessed February 18, 2020.

6. WHO. Global hepatitis report. 2017. Available from: https:// wwwwhoint/hepatitis/publications/global-hepatitis-report2017/en/. Accessed February 17, 2020.

7. Abbas Z, Siddiqui AR. Management of hepatitis B in developing countries. World J Hepatol. 2011;3(12):292-299. doi:10.4254/wjh.v3. i12.292

8. Ott JJ, Stevens GA, Groeger J, Wiersma ST. Global epidemiology of hepatitis B virus infection: new estimates of age-specific HBsAg seroprevalence and endemicity. Vaccine. 2012;30(12):2212-2219. doi:10.1016/j.vaccine.2011.12.116 
9. Razavi-Shearer D, Razavi H. Global prevalence of hepatitis B virus infection and prevention of mother-to-child transmission - authors' reply. Lancet Gastroenterol Hepatol. 2018;3(9):599. doi:10.1016/ S2468-1253(18)30199-7

10. Blumberg BS. Sex differences in response to hepatitis B virus. Arthritis Rheum. 1917;22:11.

11. WHO. Hepatitis B and breastfeeding. 1996. Available from: https:// wwwwhoint/maternal_child_adolescent/documents/pdfs/hepatitis_b_ and_breastfeedingpdf. Accessed February 26, 2020.

12. Tanga AT, Teshome MA, Hiko D, Fikru C, Jilo GK. Sero-prevalence of hepatitis B virus and associated factors among pregnant women in Gambella hospital, South Western Ethiopia: facility based cross-sectional study. BMC Infect Dis. 2019;19(1):602. doi:10.1186/ s12879-019-4220-z

13. Zhang Z, Chen C, Li Z, Wu YH, Xiao XM. Individualized management of pregnant women with high hepatitis B virus DNA levels. World J Gastroenterol. 2014;20(34):12056. doi:10.3748/wjg.v20. i34.12056

14. Khan T, Jung IH, Khan A, Zaman G. Classification and sensitivity analysis of the transmission dynamic of hepatitis B. Theor Biol Med Model. 2017;14(1):22. doi:10.1186/s12976-017-0068-3

15. Bertoletti A, Kennedy PT. The immune tolerant phase of chronic HBV infection: new perspectives on an old concept. Cell Mol Immunol. 2015;12(3):258-263. doi:10.1038/cmi.2014.79

16. USNMR. Update on diagnosis, management, and prevention of hepatitis B virus infection. Clin Microbiol Rev. 1999;12(2):351-366. doi:10.1128/CMR.12.2.351

17. Jinlin Hou ZL, Fan G. Epidemiology and prevention of hepatitis B virus infection. Int J Med Sci. 2005;2(1):50.

18. Negero A, Sisay Z, Medhin G. Prevalence of hepatitis B surface antigen (HBsAg) among visitors of Shashemene General Hospital voluntary counseling and testing center. BMC Res Notes. 2011;4 (1):35. doi:10.1186/1756-0500-4-35

19. Belyhun Y, Maier M, Mulu A, Diro E, Liebert UG. Hepatitis viruses in Ethiopia: a systematic review and meta-analysis. BMC Infect Dis. 2016;16(1):761. doi:10.1186/s12879-016-2090-1

20. Yazie TD, Tebeje MG. An updated systematic review and meta-analysis of the prevalence of hepatitis B virus in Ethiopia. BMC Infect Dis. 2019;19(1):917. doi:10.1186/s12879-019-4486-1

21. Kebede KM, Abateneh DD, Belay AS. Hepatitis B virus infection among pregnant women in Ethiopia: a systematic review and meta-analysis of prevalence studies. BMC Infect Dis. 2018;18 (1):322. doi:10.1186/s12879-018-3234-2

22. Amsalu A, Ferede G, Eshetie S, Tadewos A, Assegu D. Prevalence, infectivity, and associated risk factors of hepatitis B virus among pregnant women in Yirgalem Hospital, Ethiopia: implication of screening to control mother-to-child transmission. J Pregnancy. 2018;2018:8435910. doi:10.1155/2018/8435910

23. Gedefaw G, Waltengus F, Akililu A, Gelaye K. Risk factors associated with hepatitis $\mathrm{B}$ virus infection among pregnant women attending antenatal clinic at Felegehiwot referral hospital, Northwest Ethiopia, 2018: an institution based cross sectional study. BMC Res Notes. 2019;12(1):509. doi:10.1186/s13104-019-4561-0
24. Yohanes T, Zerdo Z, Chufamo N. Seroprevalence and predictors of hepatitis $\mathrm{B}$ virus infection among pregnant women attending routine antenatal care in Arba Minch Hospital, South Ethiopia. Hepat Res Treat. 2016;2016:9290163. doi:10.1155/2016/9290163

25. Shiferaw F, Letebo M, Bane A. Chronic viral hepatitis: policy, regulation, and strategies for its control and elimination in Ethiopia. BMC Public Health. 2016;16(1):769. doi:10.1186/s12889-016-34591

26. ECSA. Summary and statistical of report of the 2007 population and housing censes. 2007. Available from: https:/wwwethiopianreview com/pdf/001/Cen2007 firstdraft(1)pdf. Accessed February 18, 2020.

27. Semaw A, Awet H, Yohannes M. Sero-prevalence of hepatitis B surface antigen and associated factors among pregnant mothers attending antenatal care service, Mekelle, Ethiopia: evidence from institutional based quantitative cross-sectional study. World Acad Sci Eng Technol. 2015;2:9.

28. Africa H, Assegid S, Abrha H. Sero-prevalence of HBSAg and factors among pregnant women in Ethiopia. 2014.

29. World Medical Association. Declaration of helsinki; ethical principles for medical research involving human subjects. 2008. Available from: https://www.wma.net/wp-content/uploads/2018/07/DoHOct2008.pdf. Accessed December 29, 2020.

30. Franco E, Bagnato B, Marino MG, Meleleo C, Serino L, Zaratti L. Hepatitis B: epidemiology and prevention in developing countries. World J Hepatol. 2012;4(3):74-80. doi:10.4254/wjh.v4.i3.74

31. Sangkomkamhang US, Lumbiganon P, Laopaiboon M. Hepatitis B vaccination during pregnancy for preventing infant infection. Cochrane Database Syst Rev. 2014;11:CD007879.

32. Bittaye M, Idoko P, Ekele BA, Obed SA, Nyan O. Hepatitis B virus sero-prevalence amongst pregnant women in the Gambia. BMC Infect Dis. 2019;19(1):259. doi:10.1186/s12879-019-3883-9

33. Rajendiran S, Gopalan U, Jayakumar K. Seroprevalence of hepatitis $\mathrm{B}$ infection among pregnant women in South India. Int $J$ Reprod Contracept Obstet Gynecol. 2016;6(1):249. doi:10.18203/2320-1770. ijrcog20164668

34. Choisy M, Keomalaphet S, Xaydalasouk K, Quet F, Latthaphasavang V, Buisson Y. Prevalence of hepatitis B virus infection among pregnant women attending antenatal clinics in Vientiane, Laos, 2008-2014. Hepat Res Treat. 2017;2017:1284273. doi: $10.1155 / 2017 / 1284273$

35. Mac PA, Suleiman AC, Airiohuodion PE. High prevalence of hepatitis $\mathrm{B}$ virus infection among pregnant women attending antenatal care in Central Nigeria. J Infect Dis Epidemiol. 2019;5(1):068.

\section{Publish your work in this journal}

The International Journal of Women's Health is an international, peerreviewed open-access journal publishing original research, reports, editorials, reviews and commentaries on all aspects of women's healthcare including gynecology, obstetrics, and breast cancer. The manuscript management system is completely online and includes a very quick and fair peer-review system, which is all easy to use Visit http://www.dovepress.com/testimonials.php to read real quotes from published authors. 